\section{Evaluation of Factors Affecting on Safety Performance at High Workplace in Gaza Strip 2014}

\section{Alnunu MZ* and Maliha MR}

College of Applied Engineering and Urban Planning, University of Palestine, Palastine

"Corresponding author: Alnunu MZ, College of Applied Engineering and Urban Planning, University of Palestine, PO Box 1075, Gaza, Palestine, Tel: +972 8 2632001; E-mail: Mahdi_alnono@hotmail.com

Rec date: Jan 21, 2015, Acc date: Feb 24, 2015, Pub date: Mar 04, 2015

Copyright: ( 2015 Alnunu MZ, et al. This is an open-access article distributed under the terms of the Creative Commons Attribution License, which permits unrestricted use, distribution, and reproduction in any medium, provided the original author and source are credited.

\begin{abstract}
The construction industry is one of the most dangerous industries due to its unique nature. A number of researches studied the safety aspect and showed a high number of injuries and deaths at project sites. This research objective is that the sources of dangers at project sites including falling from height and knowing the methods and the worthiness of personal protection to minimize such incidents as well as improve the safety methods used. To gather information, the study used a questioner that was distributed to 70 Construction Company. The study concluded that the most targeted class exposed to fall accident in the site were the workers. Most of the results fall from height was death or injury and the Safety Awareness responsibility is the safety engineer. The most dangerous element of projects was the scaffolding and Factors related to Human and Psychological Climate. Such incidents the effect of fall accidents is project cost increase. The research recommend providing a safe environment and implementing a safety guideline with a presence of a safety engineer at project site.
\end{abstract}

Keywords: Gaza strip; Construction site; Safety management

\section{Introduction}

Construction is one of the nation's largest industries, employing about 8 million workers in 2007 [1]. Approximately 56\% of construction work is performed in residential settings; including 13\% residential building, $8 \%$ residential finishing, and $31 \%$ specialty trades [1]. In 2007, falls from heights accounted for $43 \%$ of the fatalities in residential building, which is higher than in the overall construction sector [2]. Residential construction workers are frequently exposed to working conditions that place them at risk of falling from heights, which can be especially hazardous to inexperienced workers.

The industry has contributed significantly to Malaysian's economy; this does not mean Malaysia can settle down comfortably. Often known as "dirty", "dangerous" and "difficult", this industry has been plagued by a high number of fatality rates on construction sites. Construction sites itself is commonly known as the most hazardous workplace. Current investigation from Department of Safety and Health (DOSH) has shown that construction sites have the highest death toll among all the industries [3]. Thus, construction industry became the most crucial industry in the need of effective safety measures and safety management system in the effort to achieve better safety performance [4].

Construction industry has complexity in its nature because it contains large number of parties as clients, contractors, consultants, stakeholders, shareholders, regulators and others. Construction projects in the Gaza Strip suffer from many problems and complex issues in performance such as cost, time and safety [5].

\section{Construction safety in Gaza strip}

In Palestine, the local construction industry is one of the main economic driving sectors, supporting the Palestinian national economy. It contributes to $26 \%$ of the Palestinian GDP. This is a relatively high proportion covered by this sector comparing to what is mentioned by Chitkara in that construction industry accounts 6-9 \% of GDP in many countries. However, many local construction projects report poor performance [6].

The study concludes that management of owners, consultants, and contractors are all aware of the importance of safety in construction. However, they do not actively pursue the effective ways to achieve the safety goals and research recommended to activate the roles of government, insurance, designer, consultant, owner, and contractor. Government should develop and oblige construction safety regulations. Government and insurance should arrange construction site visits to insure the application of safety measures in the sites. Consultants should participate to improve the validity and the sufficiency of the safety provisions in the contracts. Contractors should carry out a detailed safety work plan which gives an opportunity to perform each task safely [7].

Details about causes and physical conditions of construction injuries have been insufficient or almost non-existent in Palestine, in particular, and in the Middle East in general. The available information and data on this subject is too generic and does not provide enough guidance so that more effective accident prevention programs can be developed. A poor safety record is one of the most difficult challenges to face the Gaza Strip construction industry over the last few years. The rate of fatalities and injuries in construction is high relative to other industries. According to the report of the Ministry of Labour, $31 \%$ of workers who died in the Gaza Strip were construction workers. The report further states that $19.5 \%$ of reported injured workers in the Gaza Strip are construction workers [8]. 


\section{Fall worker from high construction}

Falls are the major cause of injuries and fatalities in the U.S. construction industry. Although there is a gradual decline observed in the work related injuries and fatalities in construction industry, fall accidents didn't experience any considerable improvement [9].

The most commonly types of accident in construction site are; falling (22.2\%), Stepping on the object (18.2\%) and Stroked by falling object $(17.1 \%)$. This finding coincides with latest accident data obtained from [10], which indicates that falls is the major type of accident in Malaysia construction sites [11].

Beavers et al. [12] reported that "lack of fall protection" and "misuse of fall protection" was the leading contributing factors for falls resulting from structural steel erection works. This study has also pointed out the situations when the workers tend to unhook their fall protection in order to relax or change their locations, and that was the instant when the accident happened. The researchers emphasized the need of increased efforts in training and awareness about the usage of fall protection in the structural steel erection trade, as there are a good number of persons using it. However, they are being used in the wrong manner.

The US Department of Labor [13] has 11 categories for fatal falls. These include (1) falls from stairs or steps, (2) falls through existing floor openings, (3) falls from ladders, (4) falls through roof surfaces (including existing roof openings and skylights), (5) falls from roof edges, (6) falls from scaffolds or staging, (7) falls from building girders or other structural steel, (8) falls while jumping to a lower level, (9) falls through existing roof openings, (10) falls from floors, docks, or ground level, and (11) other non-classified falls to lower levels.

\section{Causes of fall}

In this study, lack of training and awareness, ignorance and fail to comply with legal and site requirements, inadequate of procedures and system and safe work methods, inadequate safety management system and monitoring mechanism and Human Factors are the five contributing factor identified. Further analysis reveals that lack of procedures and system of work was the most important factor that causes falls from height followed by lack of training and awareness. Besides both, inadequate safety management system and unavailability of proper monitoring mechanism also lead to poor management in mitigating height works. The study would beneficial to organization and safety practitioner to deploy the right strategy and allocate sufficient resources in mitigating height related works and its hazards [14].

Accidents are result of many contributing factors, causes, and sub causes. Some of the critical factors are unsafe method, human element, unsafe equipment, job site conditions, management, and unique nature of the industry [15]. However, some of the causes are low in frequency of occurrence. The main cause of construction accidents found are the workers' negligence, failure of workers to obey work procedures, work at high elevation, operating equipment without safety devices, poor site management, harsh work operation, low knowledge and skill level of workers, failure to use personal protective equipment's and poor workers attitude about safety.

Accident occurs due to root causes:

- Failing to identify an unsafe condition that existed before an activity was started or that developed after an activity was started.
- Deciding to proceed with a work activity after the worker identifies an existing unsafe condition.

- Deciding to act unsafe regardless of initial condition of the work environment.

Tam et al. [16] did a study in China and noticed that the causes of accidents were due poor safety awareness from top leaders; lack of training; poor safety awareness of project managers; reluctance to input resources for safety; reckless operation; lack of certified skill labor; poor equipment; lack of first aid measures; lack of rigorous enforcement of safety regulation; lack of organizational commitment; low education level of workers; poor safety conscientiousness of workers; lack of Personal Protective Equipment (PPE); ineffective operation of safety regulation; lack of technical guidance; lack of strict operational procedures; lack of experienced project managers; shortfall of safety regulations; lack of protection in material transportation; lack of protection in material storage; lack of teamwork spirits; excessive overtime work for labor; shortage of safety management manual; lack of innovative technology; and poor information flow.

\section{Scaffolding identification}

Platforms should never be less than $600 \mathrm{~mm}$ in width if used for access and working or $800 \mathrm{~mm}$ if used also for materials. Where there is a risk of falling more than $2 \mathrm{~m}$, the outer edge and ends of a working platform should be protected by a rigid guard Rail, secured to the standards at a height of between 0.91 and $1.15 \mathrm{~m}$ above the Platform. To prevent materials falling off the platform, a toe board rising at least $150 \mathrm{~mm}$ above the platform should be provided along its outer edge, again secured to the standards [17].

According to Aneziris et al. [18] he classified principles involving the safety of the scaffold: 1)Strength of scaffold 2) Stability of scaffold 3) Stability of user on the scaffold 4) Edge protection to the scaffold worker 5) Scaffold structure design and construction 6) Anchoring of scaffold on building or structure 7) Foundation-base structure 8) Scaffold object protection 9) Scaffold floor condition 10) Falling object protection 11) User ability to stay on scaffold.

\section{Ladder identification}

The latter are modeled by the three events: (a) strength of ladder, (b) stability of ladder and (c) stability of user.

a) Strength of ladder: The ladder should be able to support the user along with any equipment or material he carries. If the strength of the ladder becomes lower than the stress induced by the combined load then the ladder can no longer provide the necessary support to maintain the user at the proper height. Two possible outcomes or states are defined for this event, which are success and failure. b) Stability of ladder: The ladder should be able to support the user along with any equipment or material he carries. In addition to providing adequate strength, the ladder should provide a platform of stable equilibrium for the user. If the ladder loses its stability then the user cannot remain at his position at a height. This event has two states: success and failure. c) Stability of user on the ladder: Given a strong and stable ladder, the user should be able to climb up and down and remain on the ladder without losing his stability. This event is also defined as having two states success and failure. Occurrence of loss of strength, or loss of ladder stability or loss of user stability, combined with the ladder mission result in a fall from the ladder. That is the occurrence or not of a fall is determined by the outcome of these three events. For this reason they are called primary events [18]. 


\section{Roof identification}

A previous analysis of data indicated that a total of 432 deaths occurred when workers fell through roof holes, floor holes, and skylights during the nine-year period of 1992-2000 (yearly average of 48 deaths( [19]. A follow-up analysis of the data for the five-year period of 2003-2007 has indicated that 333 workers lost their lives from falling through roof holes, floor holes, and skylights for a yearly average of 67 worker deaths, a $39.6 \%$ increase in these types of deaths since the 1992-2000 time period. The 333 fatalities are $9.6 \%$ of the total fall-to- lower-level fatal incidents that occurred in all U.S. industries during 2003-2007.

According to Lipscomb et al. [20], the majority of falls are associated with three fall hazards: working on roofs, ladders, and scaffolds. Two of the three hazards are germane to the job of roofing workers. This fact suggests that the likelihood of roofing workers getting injured is often higher than other trade workers. And indeed, the incident rate of roofing workers has been documented to be higher than the average construction trades worker; falls from heights are the primary event source leading to fatal injuries among roofing contractors accounting for $77 \%$ of all fatalities. Therefore, developing and implementing safety measures to reduce fall injuries and accidents in the roofing industry are paramount.

\section{Safety procedures}

\section{Safety education}

It is widely accepted in the construction industry that training plays an important role in worker safety. Worker training typically begins with worker orientation and continues as workers need to become more informed about certain aspects of the work they are doing. These additional training sessions may include topics such as confined space entry, hot work, traffic control, procedures, and a wide assortment of other topics, whether to introduce new information or merely to provide a refresher on a subject [21].

\section{Safety regulation}

In the studies of Kartam, Flood and Koushki [22] and Tam, Zeng and Deng [16] in Kuwait and China respectively, there was a consensus between the respondents of their surveys that safety regulation is significant to reduce accident in the construction sites. The conclusion is that the accidents caused by a wide range of factors, some of which are lack of awareness of safety regulation and the lack of enforcement of safety regulation.

\section{Safety meetings}

A well planned safety meeting is an excellent morale builder. When an employee is convinced that his employer is concerned about his on the job safety, the employee will conform to the safety rules and perform his work in a safe manner [23]. To make safety meetings more effective, there is a need for more practical and current subject material given by a variety of qualified speakers. They might come from outside, from either the union or the company itself. Smaller meetings for specific crafts also may be appropriate, with more discussion dealing with immediate problems. For crews, which have a variety of work assignments, discussion of the safety aspects of each new assignment might be held before the task, is begun [24].

\section{Safety inspection}

Safety inspections are one means by which project managers and site supervisors can become acquainted with the nature of the safety conditions on-site. Jobsite safety inspections by the forepersons are helpful in terms of reducing work injuries [21]. The use of safety inspections has been shown to have a positive effect on a company's loss control initiative. In fact companies who perform safety inspections have fewer accidents incidents than companies that do not perform inspections $[25,26]$.

\section{Emergency preparedness}

Establishing a system to efficiently manage potential injuries and emergency processes involved: Researching medical and other support services in the area, Ensuring the first aid kit was sufficiently stocked to address all identified potential emergency, Allocating first aid duties to qualified habitat personnel and providing training to those who may attend the site during the course of construction and were willing to undertake the role of First Aid Officer [21].

\section{Research methodology}

This part of the research will clarify details of methodology. This study uses the following techniques: review of literature related to the workers safety performance, the information about the research design, research population, research location, pilot study, questionnaire design, questionnaire validity, questionnaire reliability, research structure and statistical data analysis.

We have used Kish equation to determine sample size; It is the most popular equation to estimate the sample size, the following formula shows Kish equation.

$$
\mathrm{N}=\frac{\mathbf{n}^{\prime}}{1+\left(\mathbf{n}^{\prime} / \mathbf{n}\right)}
$$

$\mathrm{N}$ : sample size from finite population

$\mathrm{n}$ : total number of population

$n^{\prime}=$ sample size from infinite population, where $n^{\prime}=S^{2} / V^{2}$

$\mathrm{V}=$ Standard error of sample population equal 0.05 for the confidence level 95\%

$\mathrm{S}^{2}=$ Standard error variance of population elements, maximum value is 0.5

$$
\begin{aligned}
& \mathrm{n}^{\prime}=\mathrm{S}^{2} / \mathrm{V}^{2}=(0.5) 2 /(0.05) 2=100 \\
& \mathrm{~N}=\frac{100}{1+\left(\frac{100}{232}\right)}, \text { So } \mathrm{N}=69.87 \approx 70 \text { samples }
\end{aligned}
$$

We have 232 contractor companies, we have distributed the questionnaire to 80 individuals, were received 70 questionnaire from this survey, the rest of the questionnaires have not been recovered or rejected packaged.

\section{Results and Analysis}

Table 1 shows that the majority of implemented projects have an average size of $0-15$ projects in the last 5 years which represents $65.8 \%$ of the overall percentage according to the questionnaire, site engineer job title represents $48.6 \%$ of the job titles in the construction industry in the Gaza strip, worker which represents $87.1 \%$ is the most 
Page 4 of 5

targeted class exposed to fall accidents in the site, injury which represents $45.7 \%$ is the most frequent result to fall from height and safety engineer which represents $48.6 \%$ is the responsible for the awareness of the individuals working in the construction industry. This indicates that workers have to be aware to follow the safety rules in the site as it is very important to appoint to the existence of the safety engineer in the site.

\begin{tabular}{|c|c|c|c|}
\hline Item & Categories & $\begin{array}{l}\text { Frequenc } \\
\text { y }\end{array}$ & Percent $\%$ \\
\hline \multirow{4}{*}{$\begin{array}{l}\text { The number of projects } \\
\text { implemented in the last } 5 \\
\text { years }\end{array}$} & $\begin{array}{l}\text { less than } 10 \\
\text { projects }\end{array}$ & 23 & 32.9 \\
\hline & $10-15$ projects & 23 & 32.9 \\
\hline & $16-20$ projects & 11 & 15.7 \\
\hline & 21 and more & 13 & 18.6 \\
\hline \multirow[t]{5}{*}{ Job Title } & $\begin{array}{l}\text { owner } \\
\text { project }\end{array}$ of the & 3 & 4.3 \\
\hline & Contractor & 10 & 14.3 \\
\hline & Worker & 12 & 17.1 \\
\hline & Site engineer & 34 & 48.6 \\
\hline & Other & 11 & 15.7 \\
\hline \multirow{5}{*}{$\begin{array}{l}\text { The most targeted class } \\
\text { exposed to fall accident in the } \\
\text { site }\end{array}$} & $\begin{array}{l}\text { owner } \\
\text { project }\end{array}$ of the & 1 & 1.4 \\
\hline & Contractor & 5 & 7.1 \\
\hline & Worker & 61 & 87.1 \\
\hline & site engineer & 2 & 2.9 \\
\hline & Other & 1 & 1.4 \\
\hline \multirow[t]{3}{*}{ Fall from height } & Death & 22 & 31.4 \\
\hline & Injury & 32 & 45.7 \\
\hline & Disability & 16 & 22.9 \\
\hline \multirow[t]{5}{*}{$\begin{array}{l}\text { Safety } \\
\text { responsibility }\end{array}$} & $\begin{array}{l}\text { owner of the } \\
\text { project }\end{array}$ of & 2 & 2.9 \\
\hline & contractor & 18 & 25.7 \\
\hline & the same person & 13 & 18.6 \\
\hline & Safety Engineer & 34 & 48.6 \\
\hline & Other & 3 & 4.3 \\
\hline
\end{tabular}

Table 1: Number of projects implemented in the last 5 years showing their frequency and percentage

Table 2 shows that $38.6 \%$ of the respondents agreed that the risk percentage of falls from scaffolding is very high, $37.1 \%$ of the respondents agreed that the risk of factors related to human and psychological climate is very high, $41.4 \%$ of the respondents agreed that the risk of factors related to the nature of the work is high, $42.9 \%$ of the respondents agreed that the risk of weather conditions (climate) is normal and $31.4 \%$ of the respondents agreed that the risk of lack of knowledge of safety guidelines is high. This indicates that safety procedures have to be taken under consideration seriously using scaffolding; also it is noteworthy to take the proper safety arrangements when the nature of the work is risky.

\begin{tabular}{|l|l|l|l|l|l|l|}
\hline \multirow{2}{*}{ Items } & \multicolumn{4}{l}{ Percentage } \\
\cline { 2 - 7 } & $\begin{array}{l}\text { Very } \\
\text { low }\end{array}$ & $\begin{array}{l}\text { Lo } \\
\text { w }\end{array}$ & $\begin{array}{l}\text { Norma } \\
\text { I }\end{array}$ & $\begin{array}{l}\text { Hig } \\
\text { h }\end{array}$ & $\begin{array}{l}\text { Very } \\
\text { high }\end{array}$ \\
\hline Risk percentage of the following: & 1.4 & 5.7 & 17.1 & 37.1 & 38.6 \\
\hline Scaffolding & 1.4 & $\begin{array}{l}12 . \\
9\end{array}$ & 41.4 & 28.6 & 15.7 \\
\hline Ladders & 14.3 & $\begin{array}{l}17 . \\
1\end{array}$ & 32.9 & 18.6 & 17.1 \\
\hline Roof to Human and & - & 1.4 & 25.7 & 35.7 & 37.1 \\
\hline $\begin{array}{l}\text { Factors related to } \\
\text { Psychological Climate }\end{array}$ & & 1.4 & 34.3 & 41.4 & 22.9 \\
\hline Factors related to the nature of work & - & 12.9 & 20 & 42.9 & 14.3 & 10 \\
\hline Weather conditions (climate) & 2.9 & $\begin{array}{l}15.9 \\
7\end{array}$ & 25.7 & 31.4 & 24.3 \\
\hline $\begin{array}{l}\text { Lack of knowledge of safety } \\
\text { guidelines }\end{array}$ & & & & \\
\hline
\end{tabular}

Table 2: Factors showing the percentage of risk related to safety measures

Table 3 shows that the project cost, company's reputation and dispersion in schedule are negatively high effected by the effect of fall accidents in the site with the following respondent's agreement percentage respectively of, $32.9 \%, 34.3 \%$ and $37.1 \%$.

\begin{tabular}{|l|l|l|l|l|l|}
\hline \multirow{2}{*}{ Items } & \multicolumn{4}{|l|}{ Percentage } \\
\cline { 2 - 6 } & $\begin{array}{l}\text { Very } \\
\text { low }\end{array}$ & Low & $\begin{array}{l}\text { Norma } \\
\text { I }\end{array}$ & $\begin{array}{l}\text { Hig } \\
\text { h }\end{array}$ & $\begin{array}{l}\text { Very } \\
\text { high }\end{array}$ \\
\hline $\begin{array}{l}\text { The effect of fall accidents on the } \\
\text { following: }\end{array}$ & & & & & \\
\hline Cost increase & 1.4 & 11.4 & 31.4 & 32.9 & 22.9 \\
\hline company's reputation & 1.4 & 7.1 & 34.3 & 34.3 & 22.9 \\
\hline Dispersion in schedule & 5.7 & 18.6 & 37.1 & 27.1 & 11.4 \\
\hline
\end{tabular}

Table 3: Effect of fall accidents in the site

\begin{tabular}{|l|l|l|l|l|}
\hline \multirow{2}{*}{ Safety Procedures } & \multicolumn{4}{ll}{ Agreement } \\
\cline { 2 - 5 } & $\begin{array}{l}\text { Strongly } \\
\text { disagree }\end{array}$ & Disagree & Agree & $\begin{array}{l}\text { Strongly } \\
\text { agree }\end{array}$ \\
\hline Regular safety meetings & - & 12.9 & 62.9 & 24.2 \\
\hline Regular inspection & 2.9 & 14.2 & 62.9 & 20 \\
\hline First aid plan & - & 12.9 & 45.7 & 41.4 \\
\hline Organizing location site & 1.4 & 11.4 & 45.7 & 41.4 \\
\hline
\end{tabular}

Table 4: Regular safety meetings and regular inspection 
Table 4 shows that regular safety meetings and regular inspection are from the highest recommended safety procedures with a respondent's agreement percentage of $62.9 \%$, as first aid plan and organizing location site have a percentage of $45.7 \%$.

\section{Conclusion and Recommendation}

\section{Conclusion}

The research conclude the most dangers that affect the safety at work places and the falling accidents and the most common element in the falling incidents are Factors related to Human and Psychological Climate, and Provide safety guidelines. It also shows that the safety engineer is the single person responsible for safety awareness. The most common contributing factor of falling was the scaffolding followed by ladders with a medium danger. The factors that effect of fall accidents on the construction companies are increase the cost, makes the workers scared, and dispersion in schedule. The workers refused to work with the companies that does not follow safety regulations, having regular inspection and using of specialized equipment at work site.

\section{Recommendation}

- We need to shed a light to the safety engineer in every construction site.

- Keep the stability, strength and check for all tools in the site like scaffolding, ladder and roof.

- We should care about important factors that related to Human \& Psychological Climate and the nature of work.

- We should have Regular safety meetings that can give a proper attention about safe work.

- Have Regular inspection team and emergency plan to minimize fall accident.

\section{References}

1. U.S. Bureau of Labor Statistics [BLS] (2010) Injuries, Illnesses, and Fatalities. Office of Safety, Health and Working Conditions, USA.

2. U.S. Bureau of Labor Statistics [BLS] (2007) Injuries, Illnesses, and Fatalities. Office of Safety, Health and Working Conditions, USA.

3. DOSH (2012) DOSH Annual Report. Ministry of Human Resources.

4. Lee CK, Jaafar Y (2012) Prioritization of Factors Influencing Safety Performance on Construction Sites: A Study Based onGrade Seven (G7) Main Contractors ${ }^{\text {ee }}$ Perspectives. University of Malaysia, Pahang.

5. Abu Shaban S (2008) Factors Affecting the Performance of Construction Projects in the Gaza Strip. B.Sc. Civil Engineering, The Islamic University, Palestine.

6. Enshassi A, Mohamed S, Abushaban S (2009) Factors affecting the performance of construction projects in the Gaza Strip. J Civil Eng Manage 15: 269-280.
7. Hassona A (2005) Improving Safety Performance in Gaza Strip. Master Thesis. Islamic University of Gaza, Palestine.

8. Enshassi A, Mayer PE, Mohamed S, El-Masri F (2007) Perception of Construction Managers Towards Safety in Palestine. Int J Constr Manage 7: $41-51$.

9. Siddiqui S (2014) U.S. Construction Worker Fall Accidents: Their Causes And Influential Factors. Florida International University, FIU Electronic Theses and Dissertations. Paper 1157.

10. DOSH (2011) Occupational Accidents Statistics. Ministry of Human Resources, USA.

11. Mohammed YD, Ishak MB (2013) A Study of fatal and nonfatal accidents in construction sector. Malaysian J Civil Eng 25: 106-118.

12. Beavers J, Moore J, Schriver W (2009) Steel Erection Fatalities in the Construction Industry. J Constr Eng Manage 135: 227-234.

13. US Department of Labor, Bureau of Labor statistics (2003) Occupational Injury and Illness Classification Manual, USA.

14. Nadasan S (2014) Causes contribute for fall from building edges in construction industry, University Technology Malaysia degree of Executive Master in Occupational Safety \& Health Management.

15. Abdelhamid T, Everett J (2000) Identifying Root Causes of Construction Accidents. J Constr Eng Manage 126: 1

16. Tam CM, Zeng SX, Deng ZM (2004) Identifying elements of poor construction safety management in China. Safety Sci 42: 569-586.

17. Heng SM (2007) Construction Site Safety: Legal Issues of Liability for Various Parties. Master Thesis, University of Technology, Malaysia.

18. Aneziris ON, Papazoglou IA, Baksteen H, Mudc M, Ale BJ, et al. (2008) Quantified risk assessment for fall from height. Safety Sci 46: 198-220.

19. Bobick TG (2004) Falls through roof and floor openings and surfaces, including skylights: 1992-2000. J Constr Eng Manage 130: 895-907.

20. Lipscomb HJ, Dement JM, Nolan J, Patterson D, Li L, et al. (2003) Falls in esidential carpentry and drywall installation: findings from active injury urveillance with union carpenters. J Occup Environ Med 45: 881-890.

21. Hinze J, Gambatese J (2003) Factors that Influence Safety Performance of Specialty Contractors. J Constr Eng Manage 129: 159-164.

22. Kartam N, Flood I, Koushki P (2000) Construction Safety in Kuwait: Issues, Procedures, Problems, and Recommendations. J Safety Sci 36: 163-184.

23. Fang DP, Xie F, Huang XY, Li H (2004) Factor Analysis-Based Studies on Construction Workplace Safety Management in China. Int J Project Manage 22: 43-49.

24. Thomas WH Ng, Eby LT, Sorensen KL, Feldman DC (2005) Predictors of objective and subjective career success: A meta-analysis. Pers Psychol 58: 367-408.

25. Reese CD (2003) Occupational Health and Safety Management: A Practical Approach, Lewis Publishers, UK.

26. Huang X, Fang D (2003) Construction safety training and education in China, IEJC, China. 